\title{
Az egyéni munkacélú személygépkocsi-közlekedés COVID-19 járvány következtében történő változásának néhány környezeti aspektusa Budapesten
}

\section{Some environmental impact aspects of individual work-related car use change due to COVID-19 pandemic in Budapest}

\author{
VARJÚ VIKTOR, FARKAS ORSOLYA, \\ FARKAS JENŐ ZSOLT, \\ VÉR CSABA
}

VARJÚ Viktor: tudományos főmunkatárs, KRTK Regionális Kutatások Intézete, Dunántúli Tudományos Osztály; 7621 Pécs, Papnövelde u. 22.; varju@rkk.hu; https://orcid.org/ 0000-0003-3954-4518

FARKAS Orsolya: tudományos segédmunkatárs; KRTK Regionális Kutatások Intézete, Nyugat-magyarországi Tudományos Osztály; 9022 Győr, Liszt Ferenc u. 10.; farkas.orsolya@krtk.mta.hu; https://orcid.org/0000-0002-7211-3755

FARKAS Jenő Zsolt: tudományos főmunkatárs; KRTK Regionális Kutatások Intézete, Alföldi Tudományos Osztály (Kecskeméti Csoport); 6000 Kecskemét, Rákóczi út 3.; farkasj@rkk.hu; https://orcid.org/0000-0002-4245-2908

VÉR Csaba: tudományos segédmunkatárs; Pécsi Tudományegyetem, Műszaki és Informatikai Kar, Mérnöki és Smart Technológiák Intézet, Környezetmérnök Tanszék; 7624 Pécs, Boszorkány út 2.; ver.csaba@mik.pte.hu; https://orcid.org/0000-0002-4750-936

KULCSSZAVAK: környezeti hatás; gépkocsi használat; COVID-19; kibocsátás; immisszió

Viktor VARJÚ: senior research fellow, Transdanubian Research Department, Institute for Regional Studies, CERS; Papnövelde u. 22., H-7621 Pécs, Hungary; varju@rkk.hu; https://orcid.org/ 0000-0003-3954-4518

Orsolya FARKAS: junior research fellow, West Hungarian Research Department, Institute for Regional Studies, CERS; Liszt Ferenc u. 10., H- 9022 Györ, Hungary; farkas.orsolya@krtk.mta.hu; https://orcid.org/0000-0002-7211-3755

Jenő Zsolt FARKAS: senior research fellow, Great Plain Research Department (Kecskemét Group), Institute for Regional Studies, CERS; Rákóczi út 3., H-6000 Kecskemét, Hungary; farkasj@rkk.hu; https://orcid.org/0000-0002-4245-2908

Csaba VÉR: junior research fellow, Department of Environmental Engineering, Institute of Smart Technology and Engineering, Faculty of Engineering and Information Technology, University of Pécs; Boszorkány út 2., H-7624 Pécs,Hungary; ver.csaba@mik.pte.hu; https://orcid.org/0000-00024750-9360 


\section{Bevezetés}

A gyorselemzés arra próbál meg választ keresni, hogy a veszélyhelyzet kihirdetését követően a személygépkocsi-forgalom által okozott közvetlen kibocsátás (emisszió) milyen mértékben változott. Az első számítások Budapestre készültek el. A veszélyhelyzet kihirdetése óta a budapestiek 14 millió személygépkocsival megtett kilométert, 2400 tonna közlekedési szén-dioxid (CO2) és majd' 3000 kg szénmonoxid (CO) kibocsátást spóroltak meg az otthoni munkavégzéssel.

\section{Az eredmények}

Jelen számítás azt próbálja megbecsülni, hogy a „maradj otthon” kampány munkavégzési célú személygépkocsi közlekedés csökkenésének milyen környezeti hatása van. Számos helyen olvashattuk, hogy a különböző országok, városok légszennyezési adatai a COVID-19 járvány következtében csökkentek. Bár sok légszennyezettségi adat áll rendelkezésünkre, azok jobbára immissziós adatok és egyéb légköri hatások ${ }^{1}$ (v.ö. 2. ábra) is befolyásolhatják, így a légszennyezettségi (immissziós) adatok nem feltétlenül és nem mindig a közlekedés, vagy a gyárleállás hatásait mutatják (lásd pl. 1. és 2. ábra). Érdemes ezért megnézni, hogy az otthon maradt gépjárművek mennyiben járulnak hozzá környezetünk zöldítéséhez.

1. ábra: NO2 emisszió és immisszió alakulása Budapesten 2020.03.11-31. között NO2 emmission and immission in Budapest, 11-31.03.2020

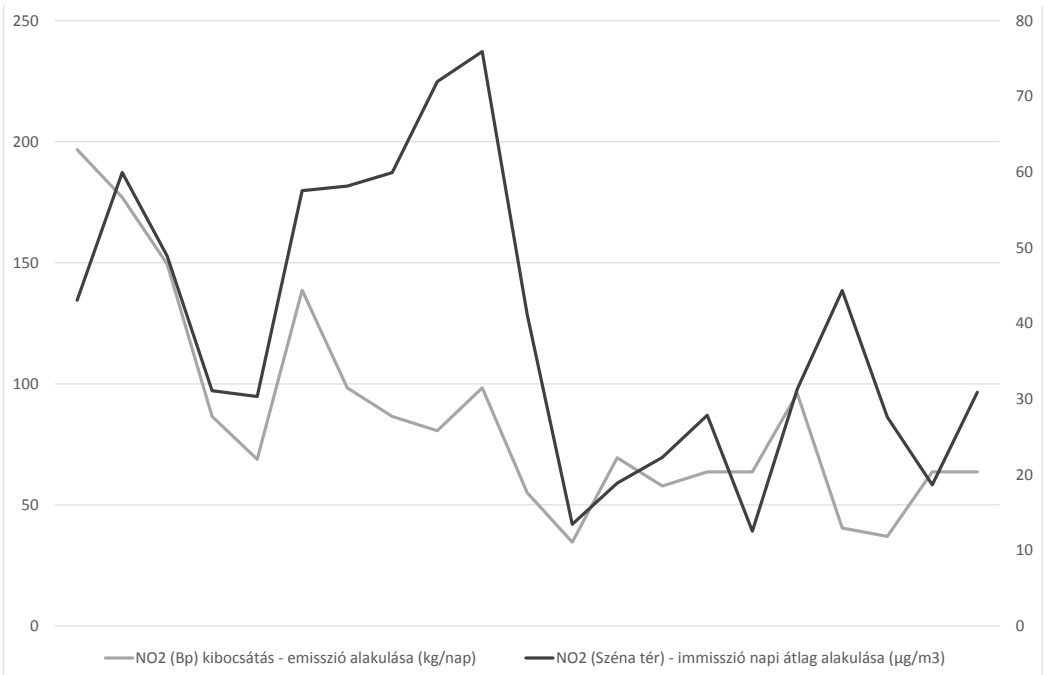

Megjegyzés: Az ábra csak az emisszió és az immiszió időbeli trendjeinek érzékeltetésére alkalmas, hiszen az emissziós és immissziós adatok mértékegysége és területi léptéke is eltér.

Forrás: Országos Légszennyezettségi Mérőhálózat automata mérőhálózat adatai, valamint saját szerkesztés 
Számításaink szerint a veszélyhelyzet kihirdetése (2020. március 11.) és kijárási korlátozás kihirdetését (2020. március 27.) követő napokban regisztrált legkevésbé forgalmas nap (2020. március 30.) között a légszennyezettség (immisszió) csökkenése mellett jól érzékelhető a személygépkocsi közlekedés és annak környezeti terhelés-csökkentése. Az említett időszak alatt (a hétvégéket nem számítva), az otthoni munkavégzéssel körülbelül 2400 tonna szén-dioxid és majd' 3000 kg szén-monoxid kibocsátást spóroltunk meg 13 munkanap alatt. A széndioxid mellett még jelentős üvegházhatású gázként nyilvántartott metán jelzett időszak alatti 6 kg-os kibocsátás-csökkentése nem tűnik soknak, ám szén-dioxid egyenértéken ez már 150 kg üvegházhatású gázt jelent. Ha az év hátralévő részében tartani tudjuk ezt a csökkentést, akkor a budapestiek összesen 40000 tonna szén-dioxid kibocsátást tudnának megspórolni. (Tegyük hozzá ez eltörpül Magyarország 15 millió tonnás háztartási, vagy 4,2 millió tonnás szállítás, raktározáshoz kapcsolódó 2017-es éves kibocsátásához. Ami azt jelenti, hogy van még hova fejlődnünk a klímaváltozás elleni harcban (KSH-STADAT 2017).)

Az említett időszak alatt a több mint $3000 \mathrm{~kg}$ ki nem bocsátott nitrogénmonoxid és nitrogén-dioxid jelentősége abban rejlik, hogy a nitrogén-oxidok légzőszervi megbetegedéseket okozhatnak, a légutak nyálkahártyájának és a szem kötőhártyájának gyulladását, a vérerek kitágulását eredményezhetik. Kritikus környezet-egészségügyi problémákat okozhat az autózás által felkavart por mellett a személygépjárművek, különösen a dízel autók porkibocsátása. Az említett

2. ábra: Szállópor és porkibocsátás alakulása Budapesten 2020.03.11-31. között. Airborne dust (PM10) and dust (PM) emmission in Budapest, 11-31.03.2020.
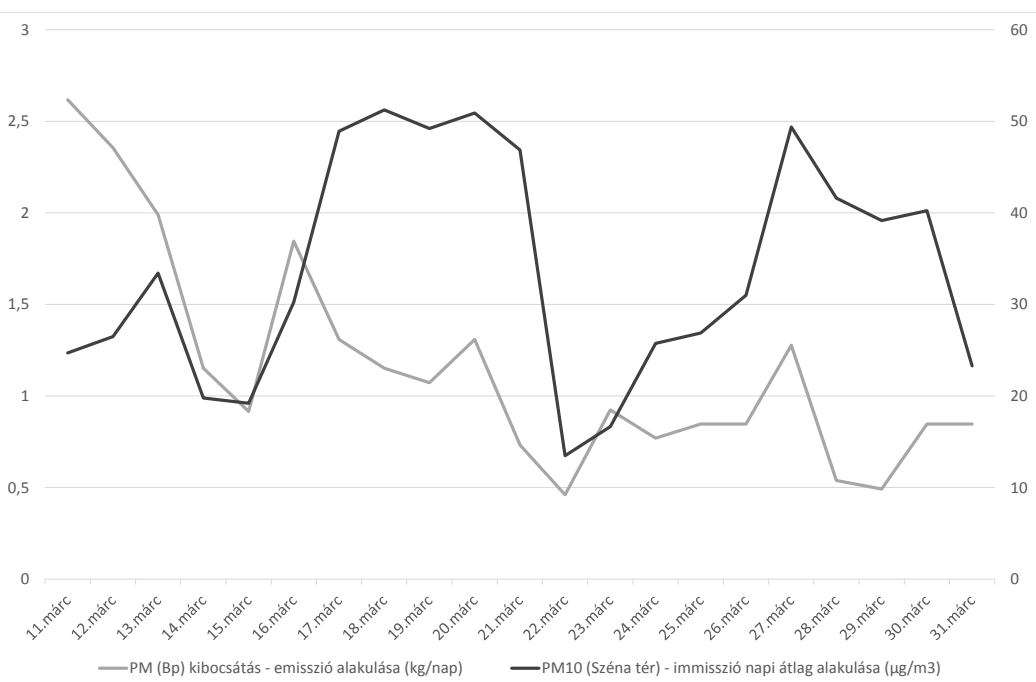

Megjegyzés: Az ábra csak az emisszió és az immiszió időbeli trendjeinek érzékeltetésére alkalmas, hiszen az emissziós és immissziós adatok mértékegysége és területi léptéke is eltér.

Forrás: Országos Légszennyezettségi Mérőhálózat automata mérőhálózat adatai, valamint saját szerkesztés 
időszak alatt 16,5 kg por ki nem bocsátásával járult hozzá a Budapesten személygépkocsit otthon hagyó munkavállaló.

A több mint $15 \mathrm{~kg}$ ki nem bocsátott SO2 azért fontos, mert a gáz az egyik legveszélyesebb légszennyező anyag, mely szintén légzőszervi megbetegedést okozhat, s az ún. savas esők fő okozója.

\section{Módszertan - a számítás menete}

Jelen írásban a munkahelyi célú közlekedésre fókuszálunk, mivel talán ez lehet az a szféra, ahol a legnagyobb eséllyel tartós változások következhetnek be (aki teheti, a járványt követően is előnyben részesíti az otthoni munkavégzést), bár egyértelműen nem ilyen arányban. Ugyanakkor az oktatási, nevelési, vagy egészségügyi motivációjú közlekedés vélhetően visszaáll a korábbi szintre.

Egy átlagos tavaszi napon a budapesti lakóhellyel rendelkező személygépkocsival közlekedők (a KSH egy 2012-es adatfelvétele szerint) közel 3 millió kilométert tesznek meg. Valójában akik vezetnek, vagy ha úgy tetszik, maguk a személygépkocsik ennek a távolságnak 83\%-át, azaz valamivel több, mint 2,5 millió kilométert tesznek meg egy átlagos hétköznapon ahhoz, hogy munkába vigyék vezetőjüket, utasaikat. (A többi kilométer az iskolába, óvodába járás, a vásárlás és számos más motiváció között oszlik meg; lásd részletesebben: KSH 2013.) A munkahelyi utazások 92\%-a településen (Budapest) belüli, s tegyük fel, ez az arány érvényes a személygépkocsival való közlekedésre is. Jelen számításnál a településen belüli utazást vettük figyelembe.

A 2018-as KSH TeIR adatok alapján a Budapesten nyilvántartott személygépkocsik 67\%-a benzin, 30\%-a gázolaj üzemü (s kevesebb mint 3\%-a gáz, elektromos vagy hibrid). Ugyanebben az évben - a KSH adatai szerint - a hazai személygépkocsi-állomány életkora 14,2 év volt (2019-ben már 14,4). Hogy minél pontosabb kibocsátási értékeket kapjunk 2020-ra vonatkozóan, a részletesebb járműállományi statisztika hiányában a 2005 januárjától bevezetett Euro 4 besorolású autók kibocsátási adataival számoltunk, s így kaptuk meg egy járvány előtti és közbeni munkanap munkába járáshoz kapcsolódó kibocsátási adatait.

Egy (2020) március eleji és végi munkanap közötti munkahelyi utazáshoz kapcsolódó forgalom-visszaesés arányának becslése is kihívásokat tartogat. Evidensnek tűnik, ha a különböző GPS adatokat használó cégek adatait próbáljuk meg felhasználni. Az index.hu által többször is citált Waze elérhető adatai ${ }^{2}$ alapján az utolsó „normális” közlekedési nap (amikor is a kormány kihirdette a veszélyhelyzetet) március 11-e, szerda volt, s az elmúlt időszak mélypontja, vagyis, amikor a legkevesebb személygépkocsi közlekedett, március 30-a volt. E (Waze) szerint a gépkocsiforgalom (személy- és tehergépkocsit is beleértve) március 30-ára a 11-i forgalom kevesebb, mint 1/4-ére (24\%) esett vissza, beleértve a teljesen megszűnő iskolai és óvodai, valamint egészségügyi intézményt látogató forgalmat, az 
erőteljesen megcsappanó vásárlási forgalmat és az egyéb ügyintézéseket (v.ö. KSH 2013 motivációs kategóriáival). (Azóta - a Waze szerint - a forgalom Budapesten körülbelül a korábbi 35\%-ára növekedett). A Google március végi mobility riportja ${ }^{3}$ Budapestre vonatkozóan 39\%-os visszaesést mutat a munkahelyre való közlekedésben, azaz e szerint a munkába járás a korábbi, normál időszak 61\%-ára esett vissza. A Magyar Közút Nonprofit Zrt. (közérdekű adatigénylésünkre küldött összefoglaló riportja ${ }^{4}$ ) szerint az M0-ás autóúton (egyelőre a hazai gyorsforgalmi utakra áll rendelkezésre publikálható formátumban értelmezhető adat) március 11. és 31. között 32\%-os forgalom-visszaesés tapasztalható (az előző év azonos időszakához képest). (A teherforgalom 5 százalékkal esett vissza.) A Budapest Közút Indexnek történt adatközlése ${ }^{5}$ alapján a budapesti hidak forgalma amely hozzávetőlegesen tükrözi a fôváros forgalmát - 2020.03.02. és 2020.03.30. között 35-40\%-os visszaesést jelez. Ahogy a fentiek mutatják, a személygépkocsiforgalom visszaesését tehát nehéz megbecsülni. Számításainkhoz a fentiek alapján az egyszerűség kedvéért 40\%-os visszaeséssel kalkuláltunk, azaz azt feltételezzük, hogy a korábbi napi 2,3 millió, munkába járó személygépkocsi által megtett km március 11. és március 30. között hozzávetőlegesen 1,38 millió kilométerre esett vissza.

\section{Néhány további módszertani megjegyzés}

A kiinduló értékekhez (munkába járás mennyisége, az átlagos munkacélú autós utak hossza) a KSH 2012-es, 15 ezer háztartásra kiterjedo", napi közlekedési szokásokat feltérképező lakossági felmérését használtuk fel. A márciusi napi adat becslésénél figyelembe vettük a KSH felmérése alapján az évszakos változásokat is.

Fontos módszertani kérdés, hogy vajon összehasonlíthatóak-e a különböző évek adatai. Mivel azonos évből nem állnak rendelkezésre adatok, ezért a fenti számításokat fenntartással kell kezelni.

A kibocsátási adatok egy életciklus elemző (LCA; Life Cycle Assessment) szoftver háttér-adatbázisából származnak, amely a lehető legtöbb, üzemeltetés során egy kilométerre vetített átlagos kibocsátási adatot veszi figyelembe különböző szakirodalmak és valós mérések alapján. Itt tehát nem az autógyárak - sokat vitatott - átlagadataival számoltunk. Benzinüzemű gépkocsiknál fele-fele arányban vettük figyelembe az $1400 \mathrm{~cm}^{3}$ alatti és az 1400-2000 cm $\mathrm{cm}^{3}$ közötti hengerürtartalmú személygépjárművek kibocsátási adatait. (Megjegyezzük, hogy a kibocsátási értékek sok anyag tekintetében azonosak. Lényegi eltérés a CO2 és az SO2 kibocsátási értékekben mutatkozik.) Gázolajüzemű gépkocsiknál az 1400-2000 cm³ közötti hengerürtartalomhoz tartozó kibocsátási adatokat vettük figyelembe. Az adatbázisban a városon belüli használatra vonatkozó kibocsátási adatokkal számoltunk.

Míg a Waze adatok vélhetőleg a gépjárművezetők (akár személygépkocsi, akár tehergépkocsi, akár buszvezetők) utazásait rögzíti (hiszen elsősorban ők használják a szoftvert aktuális forgalmi adatok és helyzetekkel kapcsolatos infor- 
mációszerzésre), addig a Google helyadatokat jóval többen használják, illetve jóval többen kapcsolják be, akár gyalog, akár tömegközeledéssel, akár egyéb gépjárművel (vezetőként vagy utasként) közlekednek. Épp ezért nehéz megbecsülni, hogy valójában a munkával kapcsolatos személygépkocsi-forgalom milyen arányban esett vissza.

\section{Jegyzetek}

1 Épp a járvány időszakában az Aral-tó kiszáradt medréből érkező porfelhő több nagyváros (pl. Debrecen, Pécs) levegőminőségét rontotta nagymértékben - https://www.met.hu/ismeret-tar/ meteorologiai_hirek/index.php?id=3686\&m=2\&hir=Porfelho_erkezett_az_Aral-to_kiszaradt_medrebol 2 http://wazestats.com/active.php?city=7

3 Google LLC "Google COVID-19 Community Mobility Reports." https://www.google.com/covid19/ mobility/ Accessed: 13.04 .2020

$4 \quad$ (2020.04.14.)

5 https://index.hu/belfold/2020/04/09/megugrott_budapest_belvarosaban_a_forgalom/ A kézirat lezárásának időpontja: 2020. április 16.

A kézirat korábbi változata, mint a KRTK Regionális Kutatások Intézete koronavírussal összefügg” gyorselemzése, „Közlekedési emisszió változásának néhány aspektusa a COVID-19 járvány következtében" címmel jelent meg, elérhetősége: http://www.docs.rkk.hu/rkkwebKornyezeti_ hatas_elemzes.pdf

\section{Felhasznált források}

KSH 2013, A lakosság közösségi és egyéni közlekedési jellemzői, 2012. Statisztikai Tükör, VII. évf. 47.sz.

KSH Stadat 2017 - Nemzetgazdasági ágak és háztartások szén-dioxid (CO2) kibocsátása (biomasszából származó szén-dioxid nélkül) (1985-2017) https://www.ksh.hu/docs/hun/xstadat/xstadat_eves/i_ua047d.html 